\title{
Therapeutic Drug Monitoring of Protein Kinase Inhibitors in Breast Cancer Patients
}

\author{
Jaroslava Roušarová, Martin Šíma, Ondřej Slanař \\ Institute of Pharmacology, First Faculty of Medicine, Charles University \\ and General University Hospital in Prague, Prague, Czech Republic \\ Received April 1, 2021; Accepted October 20, 2021.
}

Key words: Abemaciclib - Everolimus - Lapatinib - Neratinib - Palbociclib Ribociclib

\begin{abstract}
Protein kinase inhibitors (PKIs) represent up-to-date therapeutic approach in breast cancer treatment. Although cancer is a rapidly progressive disease, many substances, including PKIs, are usually used at fixed doses without regard to each patient's individuality. Therapeutic drug monitoring (TDM) is a tool that allows individualization of therapy based on drug plasma levels. For TDM conduct, exposure-response relationships of drug substances are required. The pharmacokinetic data and exposure-response evidence supporting the use of TDM for 6 PKIs used in breast cancer treatment, one of the most common female tumour diseases, are discussed in this review.
\end{abstract}

This study was supported by the Charles University Project Progres Q25 and grant No. SVV 260523.

Mailing Address: PharmDr. Jaroslava Roušarová, Institute of Pharmacology, First Faculty of Medicine, Charles University and General University Hospital in Prague, Albertov 4, 12800 Prague 2, Czech Republic; Phone: +420 224968 035; e-mail: jaroslava.rousarova@lf1.cuni.cz 


\section{Introduction}

Breast cancer is considered the most common female cancer disease worldwide (Sancho-Garnier and Colonna, 2019). It is also the most frequent cause of cancerrelated deaths in women in almost all countries except the most economically developed ones, where lung cancer holds the first place (Sancho-Garnier and Colonna, 2019). One of the recently introduced approaches in breast cancer treatment is the inactivation of protein (tyrosine or serine/threonine) kinases. Protein kinase inhibitors (PKIs) are usually used at a fixed dose with no focus on dose individualization. This one-size fits to all strategy could lead in individual patients to suboptimal anticancer effect (underdosing) or to the development of toxicity (overdosing) as the inter-individual variability in pharmacokinetics is very high (Gougis et al., 2019). However, there are no biomarkers for efficacy prediction for any of the 6 PKIs (Table 1) available for the breast cancer therapy. The treatment effect is usually evaluated using radiological assessments every 8-12 weeks, however, the regulation of effective plasma concentration could be beneficial at an early stage of the treatment to stop the progression of the disease as soon as possible (Groenland et al., 2019). Therapeutic drug monitoring (TDM) could be a convenient way for the prediction of treatment response.

TDM directly clarifies the actual drug concentration in serum and allows dosing optimization based on simulated pharmacokinetic parameters of either $\mathrm{C}_{\max }$, $\mathrm{C}_{\text {trough, }}$, or AUC (area under the curve) derived from a population pharmacokinetic model and adjusted to individual patients' characteristics (Herviou et al., 2016). This approach could improve anticancer treatment efficacy if there was a suitable and predictive pharmacokinetic (PK) parameter. Moreover, PKIs possess a narrow therapeutic window, a significant pharmacokinetic variability and the therapy spans over long time (Groenland et al., 2019). Nevertheless, the exposure-response relationships are not clearly defined for PKIs (Yu et al., 2014). Therefore, the aim of this review is to summarize previously published exposure-response relationships on all six PKIs, which could be used for TDM of PKIs to personalize the treatment in the future.

\section{Literature search and evidence level appraisal}

PubMed and Web of Science databases have been searched till February 2021. The key words used for the searches were TDM, therapeutic drug monitoring, pharmacokinetics, and pharmacokinetic target plus tyrosine kinase inhibitor (TKI), $\mathrm{PKI}$, or names of each of $6 \mathrm{PKIs}$. A total of 1,264 reports have been found using these criteria, which were subsequently screened for the relevance to the aim of this review. There were 5, 11, 6, 4, 6, and 3 relevant publications found for abemaciclib, everolimus, lapatinib, neratinib, palbociclib, and ribociclib, respectively.

Evidence level evaluation derived from Verheijen et al. (2017) was used to characterize the significance of a pharmacokinetic parameter for potential utilization in TDM. Evidence level I, II, and III was used if prospective studies have been already 
Table 1 - PKIs used in breast cancer therapy (source: SmPCs, www.ema.europa.eu)

\begin{tabular}{lcr}
\hline PKIs & Mechanism of action & \multicolumn{1}{c}{ Dosing } \\
\hline Abemaciclib & CDK 4/6 inhibitor & $150 \mathrm{mg}$ Q12H \\
Everolimus & mTOR inhibitor & $10 \mathrm{mg} \mathrm{Q24H}$ \\
Lapatinib & EGFR/HER2 inhibitor & $1250 \mathrm{mg}$ Q24H \\
Neratinib & EGFR/HER2 inhibitor & $240 \mathrm{mg}$ Q24H \\
Palbociclib & CDK 4/6 inhibitor & $125 \mathrm{mg} \mathrm{Q24H}$ \\
Ribociclib & CDK 4/6 inhibitor & $600 \mathrm{mg}$ Q24H \\
\hline
\end{tabular}

$\mathrm{PKls}$ - protein kinase inhibitors

performed, if at least two studies showed similar pharmacokinetic values potentially useful for TDM and prospective studies conducting to confirm these values are required in the future, and if pharmacokinetic values came from one study only or from more highly inconsistent studies, respectively.

\section{Pharmacokinetics of PKIs}

Since knowledge of pharmacokinetics is essential for the right implementation of TDM, we include a brief pharmacokinetic characteristics of individual PKIs. The basic pharmacokinetic parameters are then summarized in Table 2.

\section{Abemaciclib}

Median $T_{\max }$ and $t_{1 / 2}$ ranged from 4 to $6 \mathrm{~h}$ and 17.4 to $38.1 \mathrm{~h}$, respectively. When patients with solid tumours were treated with $150 \mathrm{mg}$ twice daily, steady-state $\mathrm{AUC}_{0-24}$ reached $4,280 \mathrm{ng} \times \mathrm{h} / \mathrm{ml}$, and the mean steady-state $C_{\max }$ was $249 \mathrm{ng} / \mathrm{ml}$

Table 2 - Basic pharmacokinetic parameters of PKIs

\begin{tabular}{lcccrl}
\hline & $\begin{array}{c}\text { Half-life } \\
\mathbf{( h )}\end{array}$ & $\begin{array}{c}\text { Steady- } \\
\text { state } \mathbf{C}_{\max } \\
\mathbf{( n g / m )}\end{array}$ & $\begin{array}{c}\mathbf{T}_{\text {max }} \\
\mathbf{( h )}\end{array}$ & $\begin{array}{c}\text { Steady- } \\
\text { state AUC } \\
\text { (ng×h/ml) }\end{array}$ & References \\
\hline Abemaciclib & $17.4-38.1$ & 249 & $4-6$ & 4280 & Patnaik et al. (2016) \\
\hline Everolimus & 30.0 & 61.0 & $0.5-2.5$ & 514 & Gombos et al. (2015) \\
\hline Lapatinib & 24.0 & 2470 & 3.0 & 31900 & Chu et al. (2008) \\
\hline Neratinib & 14.0 & 74.0 & 4.0 & 939 & Kourie et al. (2016) \\
\hline Palbociclib & 25.9 & 97.4 & 5.5 & 1733 & Flaherty et al. (2012) \\
\hline Ribociclib & 32.6 & 2100 & $1-5$ & 28200 & $\begin{array}{l}\text { Infante et al. (2016), } \\
\text { Curigliano et al. } \\
\text { (2017) }\end{array}$ \\
\hline
\end{tabular}

PKIs - protein kinase inhibitors; AUC - area under the curve 
(Patnaik et al., 2016). The absorption of abemaciclib was not affected by food intake (Thill and Schmidt, 2018).

\section{Everolimus}

The absorption of everolimus was rapid with $\mathrm{T}_{\max }$ from 0.5 to $2.5 \mathrm{~h}$ and the half-life was about $30 \mathrm{~h}$. After $10 \mathrm{mg}$ per day dosing in patients, $\mathrm{C}_{\max }$ and $\mathrm{AUC}$ were $61 \pm 17 \mathrm{ng} / \mathrm{ml}$ and $514 \pm 231 \mathrm{ng} \times \mathrm{h} / \mathrm{ml}$, respectively (Gombos et al., 2015). High-fat meal reduced $C_{\max }$ and $A \cup C$ by an average of $60 \%$ and $16 \%$ when compared with treatment under fasting conditions (Falkowski and Woillard, 2019).

\section{Lapatinib}

The maximum plasma concentration of lapatinib was reached from 3 to $4 \mathrm{~h}$ after the administration and its $t_{1 / 2}$ was $24 \mathrm{~h}$. Steady-state $C_{\max }$ and $A \cup C$ reached $2.47 \mu \mathrm{g} / \mathrm{ml}$ and $31.9 \mu \mathrm{g} \times \mathrm{h} / \mathrm{ml}$, respectively (Chu et al., 2008). There was the only active metabolite GW690006 reported responsible for the inhibition of EGFR (van Erp et al., 2009).

Extreme variability in AUC (6-fold) was observed in patients treated with 1,200-1,500 mg lapatinib (Klumpen et al., 2011). In comparison with fasting state, $A \cup C$ and $C_{\max }$ reached 3.0-fold and 3.2-fold higher values when lapatinib was administered with low-fat breakfast (Burris et al., 2009). Thus, lapatinib should be taken on an empty stomach (Stein and Mann, 2016).

\section{Neratinib}

After a therapeutic dose of $240 \mathrm{mg}$ per day given with food, the mean $\mathrm{T}_{\max }$ was observed after $4 \mathrm{~h}$ and the average $t_{1 / 2}$ was approximately $14 \mathrm{~h}$. Mean $\mathrm{C}_{\max }$ of $74 \mathrm{ng} / \mathrm{ml}$ and mean $\mathrm{AUC}_{0-24}$ of $939 \mathrm{ng} \times \mathrm{h} / \mathrm{ml}$ were observed after 3 weeks of treatment (Kourie et al., 2016).

\section{Palbociclib}

$\mathrm{C}_{\max }$ of $97.4 \mathrm{ng} / \mathrm{ml}(\mathrm{CV}=41 \%)(\mathrm{CV}$ - coefficient of variation) was achieved with $\mathrm{T}_{\max }$ of $5.5 \mathrm{~h}(2.0-9.8)$ on day 21 of the treatment with $125 \mathrm{mg}$ once daily. $\mathrm{AUC}_{0-24}$ was $1,733 \mathrm{ng} \times \mathrm{h} / \mathrm{ml}(\mathrm{CV}=42 \%)$ and $\mathrm{t}_{1 / 2}$ was $25.9 \mathrm{~h}$ (Flaherty et al., 2012). The reduction of palbociclib levels was observed in fasting conditions, thus palbociclib should be taken with food (Thill and Schmidt, 2018).

\section{Ribociclib}

Ribociclib was absorbed with median $\mathrm{T}_{\max }$ ranging from 1 to $5 \mathrm{~h}$ in patients treated with $600 \mathrm{mg}$ per day following a schedule with 3 weeks on and 1 week off treatment. The mean effective half-life was $32.6 \mathrm{~h}$ (Infante et al., 2016). The average $\mathrm{C}_{\max }$ on day 18 was 2,100 ng/ml $(\mathrm{CV}=59.3 \%)$ and $\mathrm{AUC}_{0-24} 28,200 \mathrm{ng} \times \mathrm{h} / \mathrm{ml}$ $(C V=64.7 \%)$ (Curigliano et al., 2017). The main active metabolite LEQ803 levels correlated with that of ribociclib (Infante et al., 2016). Similarly to abemaciclib, there was no food effect on ribociclib levels (Thill and Schmidt, 2018). 


\section{Therapeutic drug monitoring of PKIs}

Consistent and defined relationships between exposure and response of each drug are necessary for TDM (Groenland et al., 2019). TDM of PKIs has not become routine as the data on the exposure-response relationships and clinical benefits are insufficient, yet (Cardoso et al., 2020). Prospective clinical studies have already shown promising exposure-response relationships in case of everolimus (Groenland et al., 2019). For the other TKIs, for which pharmacokinetic targets have not been directly established, it is estimated that they reach approximately $82 \%$ of the mean population exposure observed in patients treated with approved effective doses in clinical trials (Verheijen et al., 2017). This estimate is derived from TKIs with defined PK target for other therapeutic indications.

The steady-state through concentration $\left(\mathrm{C}_{\text {trough }}\right)$ may be considered as a surrogate for systemic exposure. Thus, blood sampling should be performed just before the administration of the next dose, which means 12 hours post-dose in a twice-daily regimen and 24 hours post-dose in a once-daily regimen (Gao et al., 2012; Josephs et al., 2013). However, if blood sampling is not performed on time of $C_{\text {trough, }}$, in outpatients, PK extrapolation to though level is needed. It is also important to realize that the time for the first exposure measurement differs among all agents depending on their half-lives as a steady-state is achieved after five $t_{1 / 2}$ (Cardoso et al., 2020).

\section{Abemaciclib}

In preclinical PK/PD analysis, $C_{\text {trough }}$ threshold for the efficacy of $200 \mathrm{ng} / \mathrm{ml}$ was determined in mice bearing human tumour xenografts. This threshold is consistent with $C_{\text {trough }}$ in breast cancer patients treated with efficacious doses of abemaciclib (Tate et al., 2014, 2018).

Consistent data were observed in 5 Japanese patients suffering from advanced solid cancers treated with $200 \mathrm{mg}$ twice daily, in whom mean $\mathrm{C}_{\text {trough }}$ at steady-state reached $210 \mathrm{ng} / \mathrm{ml}(\mathrm{CV}=89 \%)$. However, in other study group, in which 2 patients were treated with $100 \mathrm{mg}$ twice daily, and another 2 patients with $150 \mathrm{mg}$ twice daily, the $C_{\text {trough }}$ in steady state ranged from 102.65 to $1,176.16 \mathrm{ng} / \mathrm{ml}$ (Fujiwara et al., 2016). Neutropenia represented the most common adverse event developed in $83.3 \%$ of Chinese patients ( $n=10$ ), followed by diarrhea, leukopenia, and decreased appetite in $75 \%$ of the patients $(n=9)$ in phase I abemaciclib study. The mean steady-state $C_{\text {trough }}$ of $202 \mathrm{ng} / \mathrm{ml}(C V=72 \%)$ was observed in 7 patients suffering from tumour diseases, including breast cancer, treated with a standard dose of $150 \mathrm{mg}$ twice daily (Zhang et al., 2021). However, it appears that neutropenia is related to $C_{\max }$ of abemaciclib and its metabolites (Groenland et al., 2020).

No relationship between abemaciclib adverse event of a change in QT interval and plasma abemaciclib concentration was found in Japanese patients (Fujiwara et al., 2016). 
Groenland et al. (2020) proposed median $C_{\text {trough }}$ values of 169 and $197 \mathrm{ng} / \mathrm{ml}$ when treated with 150 and $200 \mathrm{mg}$, respectively, as a promising target for abemaciclib TDM.

The trough level around $200 \mathrm{ng} / \mathrm{ml}$ seems to be a promising TDM target. However, more prospective clinical trials are necessary as no robust data on the exposure-response relationship were described.

\section{Everolimus}

The strategy of TDM of everolimus has already been established in pediatric oncology and transplantation medicine. In pediatric patients with oncological diagnoses, $C_{\text {trough }}$ within 5-15 ng/ml was described as the pharmacokinetic target (Verheijen et al., 2018). In transplantology, a higher number of occurrence of acute rejection was observed when $C_{\text {trough }}$ was lower than $3 \mathrm{ng} / \mathrm{ml}$ (Kirchner et al., 2004). $\mathrm{C}_{\text {trough }}$ within 3-8 $\mathrm{ng} / \mathrm{ml}$ should be targeted when treated with everolimus combined with other immunosuppressants, while $6-10 \mathrm{ng} / \mathrm{ml}$ is the range of $\mathrm{C}_{\text {trough }}$ for everolimus used in monotherapy (Shipkova et al., 2016). The relationship between everolimus exposure and occurrence of adverse effects were also explored in order to define the upper limit of everolimus therapeutic range. While frequency of thrombocytopenia and metabolic disorders increase with increasing everolimus $\mathrm{C}_{\text {trough }}$, incidence of leucopenia were relatively constant in the range of everolimus $\mathrm{C}_{\text {trough }}$ of 1-15 ng/ml (Kovarik et al., 2002; Kirchner et al., 2004).

TDM is not usually applied for everolimus in adult cancer treatment except for tuberous sclerosis complex associated subependymal giant cell astrocytoma and tuberous sclerosis complex-associated partial-onset seizures in which treatment concentrations between $5-15 \mathrm{ng} / \mathrm{ml}$ are recommended in the USA (Strobbe et al., 2020). When compared with patients with $C_{\text {trough }}$ less than $10 \mathrm{ng} / \mathrm{ml}$, median progression-free survival (PFS) was numerically higher in patients with pancreatic neuroendocrine tumours or renal cell carcinoma with $C_{\text {trough }}$ of $10-30 \mathrm{ng} / \mathrm{ml}$ (Ravaud et al., 2014). Threshold of $14.1 \mathrm{ng} / \mathrm{ml}$ was proposed for the treatment of metastatic renal cell carcinoma as the PFS was 13.3 months in patients achieving this level, while 3.9 months less if lower exposure was measured (Thiery-Vuillemin et al., 2014). Proposed range of $8.2-18.0 \mathrm{ng} / \mathrm{ml}$ has been proposed in another study in Japanese patients suffering from renal cell carcinoma. The dose reduction or treatment discontinuation took place when the median everolimus concentration reached $18.0 \mathrm{ng} / \mathrm{ml}$, while patients with dose maintenance had a mean blood concentration of $8.2 \mathrm{ng} / \mathrm{ml}$ (Takasaki et al., 2019).

For the breast, kidney, and neuroendocrine cancer treatment with everolimus, $\mathrm{C}_{\text {trough }}$ between 11.9 and $26.3 \mathrm{ng} / \mathrm{ml}$ was proposed. A 4-fold higher risk of toxicity was observed when $C_{\text {trough }}$ reached $26.3 \mathrm{ng} / \mathrm{ml}$ while a 3-fold higher risk of disease progression was associated with $C_{\text {trough }}$ lower than $11.9 \mathrm{ng} / \mathrm{ml}$ (Deppenweiler et al., 2017). $C_{\text {trough }}$ higher than $19.2 \mathrm{ng} / \mathrm{ml}$ was associated with clinically relevant toxicity. The geometric mean $C_{\text {trough }}$ was $12.6 \mathrm{ng} / \mathrm{ml}$, but the median PFS was not significantly 
different between patients with $C_{\text {trough }}$ higher or lower than $12.6 \mathrm{ng} / \mathrm{ml}$ (Willemsen et al., 2018). A review of Falkowski and Woillard (2019) based on studies involving exposure-effect relationships for everolimus in oncology considers $C_{\text {trough }}$ higher than $20 \mathrm{ng} / \mathrm{ml}$ to be a threshold connected with increased risk of overall severe toxicity. Verheijen et al. (2017) described $C_{\text {trough }}$ of $13.2 \mathrm{ng} / \mathrm{ml}$ as average everolimus exposure and recommended $\mathrm{C}_{\text {trough }}$ higher than $10 \mathrm{ng} / \mathrm{ml}$ as a promising TDM target.

At least some proportion of adverse events such as stomatitis are probably related to the $C_{\max }$. In patients with breast, renal and neuroendocrine tumours switching from once-daily $10 \mathrm{mg}$ regimen to twice-daily $5 \mathrm{mg}$ regimen led to a reduction of $32.7 \%(21.2 \mathrm{ng} / \mathrm{ml})$ in $C_{\max }(p=0.013)$ with no negative impact on $C_{\text {trough }}$ as an only modest increase in $C_{\text {trough }}$ was observed $(9.6[\mathrm{CV}=35.0 \%]$ and $13.7[53.9 \%] \mathrm{ng} / \mathrm{ml}$ when treated with $10 \mathrm{mg}$ once daily and $5 \mathrm{mg}$ twice daily, $\mathrm{p}=0.018$ ). As expected, both $A \cup C$ and $T_{\max }$ maintained with no statistically significant changes $(p=0.70$ and 0.95, respectively) (Verheijen et al., 2018).

Based on available data, the $C_{\text {trough }}$ between 10 and $20 \mathrm{ng} / \mathrm{ml}$ seems to be a promising TDM target for everolimus in breast cancer treatment. The specific attribute of everolimus is high incorporation into erythrocytes. Therefore, the whole blood should be used for everolimus quantification instead of plasma (Shipkova et al., 2016).

\section{Lapatinib}

Large PK variability (6.2-fold for $C_{\text {trough }}, 2.5$-fold for $C_{\max }$, and 6-fold for AUC) was observed in patients treated with 1,200-1,500 mg of lapatinib. This variability could be a reason for the known variation in the anti-cancer effect suggesting possible advantage of TDM in lapatinib treated patients (Klumpen et al., 2011). Neither frequency of diarrhea nor rash as the most prominent adverse events showed apparent relationship to lapatinib serum concentration (Burris et al., 2005). The diarrhea could be caused by unabsorbed lapatinib, therefore the better correlation is with dose (Klumpen et al., 2011).

The $C_{\text {trough }}$ of $480 \pm 310 \mathrm{ng} / \mathrm{ml}$ was observed in patients treated with 1,200 mg once daily for two weeks (Josephs et al., 2013). In another study, $C_{\text {trough }}$ reached the range of $300-600 \mathrm{ng} / \mathrm{ml}$ in the majority of responders treated with median dose of $900 \mathrm{mg}$ for metastatic solid tumours. However, only 4 of 67 patients treated for breast cancer showed partial responses (Burris et al., 2005). Yu et al. (2014) proposed the mean $\mathrm{C}_{\text {trough }}$ target in steady-state of around $780 \mathrm{ng} / \mathrm{ml}$. This target for the TDM conducting cannot be, however, recommended yet (Yu et al., 2014).

In the study with 21 breast cancer women treated with a combination of 1,250 mg of lapatinib and capecitabine for at least 29 days, the median lapatinib $C_{\text {trough }}$ levels reached $5,090 \mathrm{ng} / \mathrm{ml}$. These high values were probably caused by hepatic impairment, drug interactions, or non-compliance with fasting conditions. Despite the high lapatinib levels, no severe toxicity was observed, except for a woman of small stature and low weight with markedly higher levels of $11,250 \mathrm{ng} / \mathrm{ml}$ possibly 
causing hyperbilirubinemia (Cizkova et al., 2012). Similarly, high levels were observed in patients treated using an intermittent dose-escalation schedule with high doses of lapatinib up to $7,000 \mathrm{mg}$ per day in breast cancer women. Mean concentration in patients who respond to the lapatinib therapy reached $5,727 \mathrm{ng} / \mathrm{ml}$ while the mean concentration of non-responders was $2,174 \mathrm{ng} / \mathrm{ml}$. Clinically significant toxicities were noticed in $\geq 10 \%$ of patients $(n=40)$ and the most common adverse event was diarrhea. Lapatinib treatment led to the resolution of liver metastasis after 2 months, a $63 \%$ reduction in a lung metastasis after 17 months, the complete response in bulky mediastinal metastases after 1 year in 3 patients whose lapatinib serum levels exceeded 10,000 ng/ml (Chien et al., 2014).

Due to lacking exposure-response data and significant differences in $C_{\text {trough }}$ values in various studies, a specific pharmacokinetic target cannot be established for lapatinib treatment.

\section{Neratinib}

As neratinib blocks its target irreversibly, a lower efficacy threshold than the mean could be expected. Due to its irreversible covalent binding, the effect endures even after its elimination from the systemic circulation (Groenland et al., 2019).

In non-clinical mice studies, the exposure of $431 \mathrm{ng} \times \mathrm{h} / \mathrm{ml}$ was obtained after minimum efficacious dose. In a clinical study the steady-state exposure in 8 partial responders with metastatic breast cancer was about 2.2-fold higher in comparison with the mice exposure (Wong et al., 2009).

Neratinib concentration $\geq 28 \mathrm{ng} / \mathrm{ml}$ provided inhibition of autophosphorylation of ErbB2 in ErbB2-overexpressing BT474 cells in preclinical studies. Mean steadystate through concentrations measured in each of 5 study months exceeded this concentration as they ranged from 52 to $59 \mathrm{ng} / \mathrm{ml}(\mathrm{CV} \leq 62 \%)$ in 81 breast cancer patients with or without prior trastuzumab treatment treated with $240 \mathrm{mg}$ of neratinib once daily. In 52 of 59 evaluable patients with target lesion at baseline and a minimum of one follow-up, tumour size was reduced. Manageable diarrhea represents the most common adverse event (Burstein et al., 2010).

The concentration of $53.8 \mathrm{ng} / \mathrm{ml}$ was measured in a patient suffering from breast cancer with brain metastases treated with neratinib for 13 cycles after surgery. There was no disease progression for 13 cycles and the patient stayed alive for the next 3 years. The level of $53.8 \mathrm{ng} / \mathrm{ml}$ corresponds with the aforementioned range of 52 to $59 \mathrm{ng} / \mathrm{ml}$ (Freedman et al., 2020).

There is lack information about neratinib relationship between exposure and response. The target of $C_{\text {trough }}$ between 52 to $59 \mathrm{ng} / \mathrm{ml}$ could be followed and evaluated in prospective clinical studies.

\section{Palbociclib}

Only limited exposure-response data exists. To compare concentrations of palbociclib the mean $C_{\text {trough }}$ of $61 \mathrm{ng} / \mathrm{ml}(\mathrm{CV}=42 \%)$ observed in patients with 
advanced cancer and healthy subjects could be used according to Verheijen et al. (2017), Groenland et al. (2020).

Steady-state geometric mean palbociclib (used together with letrozole) $\mathrm{C}_{\text {trough }}$ was higher in Japanese $(95.4 \mathrm{ng} / \mathrm{ml})$ and other Asians $(90.1 \mathrm{ng} / \mathrm{ml})$ when compared with non-Asians $(61.7 \mathrm{ng} / \mathrm{ml})$ suffering from estrogen receptor-positive, HER-2 negative advanced breast cancer. The median PFS among Japanese $(n=46)$ was 22.2 months and 24.8 among the overall population $(n=666)$ when treated with palbociclib in combination with letrozole (Mukai et al., 2019).

Neutropenia is a familiar adverse event when treated with palbociclib and appears to correlate with increased palbociclib exposure (Verheijen et al., 2017). The maximum percent change in absolute neutrophil count correlated with AUC over dosing interval and $\mathrm{C}_{\max }$ after a 1-cycle of treatment in a study with Japanese patients suffering from advanced solid tumours (correlation coefficients -0.5292 and -0.4581 , respectively). The PFS ranges of 29 to 223 days or 28 to 280 days were gained in patients treated with 100 or $125 \mathrm{mg}$ of palbociclib, respectively. The PFS range of 31 to $\geq 592$ days was gained in patients treated with $125 \mathrm{mg}$ of palbociclib concurrently with letrozole. Mean $\mathrm{C}_{\text {trough }}$ concentration reached $88.5 \mathrm{ng} / \mathrm{ml}$ (CV $=49 \%$ ) in these patients (Tamura et al., 2016). Previous studies showed significantly prolonged PFS in patients suffering from grade 3 or 4 neutropenia. The longer PFS could be caused by the higher sensitivity of patients to palbociclib. Based on the fact that higher palbociclib levels lead to neutropenia and neutropenia lead to longer PFS, Groenland et al. (2020) find an apparent exposure-response relationship.

When palbociclib combined with letrozole, similar median PFS were observed in each of 4 quantiles based on palbociclib exposure $(24.9,27.7,25.7$, and 24.0 months) while all PFSs were higher than PFS of patients treated only with letrozole (14.5 months). This finding suggests that PFS duration is not associated with palbociclib exposure, and patients with different palbociclib exposures benefit similarly. Analogous research was conducted with palbociclib combined with fulvestrant in which average concentration for median PFS was $78.29 \mathrm{ng} / \mathrm{ml}$. Both lower and higher concentrations than 78.29 led to similar PFS (McShane et al., 2018).

On Day $21 \mathrm{C}_{\text {trough }}$ was $47.0 \mathrm{ng} / \mathrm{ml}(\mathrm{CV}=48 \%)$ in 4 patients treated with $125 \mathrm{mg}$ once daily. The efficacy was not among the aims of this study, but none of 37 patients treated with different dosages included in the study met RECIST (response evaluation criteria in solid tumours) guidelines for partial response. The only information about responses in patients treated with $125 \mathrm{mg}$ includes a patient with stable disease for $\geq 10$ cycles with a testicular tumour (Flaherty et al., 2012).

It is still necessary to evaluate TDM target values for palbociclib treatment in further prospective studies as there is not enough responsible exposure-response data.

\section{Ribociclib}

The relationships between exposure and response have not been established due to the lack of data (Shah et al., 2018). 
The steady-state geometric mean $\mathrm{C}_{\text {trough }}$ of $711 \mathrm{ng} / \mathrm{ml}(\mathrm{CV}=72.9 \%)$ was detected in 36 cancer patients treated with $600 \mathrm{mg}$ ribociclib (Samant et al., 2018). However, there is no information about efficacy.

The asymptomatic prolongation of QT interval is a treatment-related adverse event and is associated with $C_{\max }$ kinetics. The correlation between neutropenia and thrombocytopenia with exposure was also observed (Infante et al., 2016). Mean QT interval prolongation of 22.87 ms was related to the mean steady-state $C_{\max }$ of 2,237 $\mathrm{ng} / \mathrm{ml}$ (Groenland et al., 2020).

As same as in abemaciclib and palbociclib, higher ribociclib levels are associated with neutropenia (Groenland et al., 2020).

The only available value to verify in further studies is average $C_{\text {trough }}$ of $711 \mathrm{ng} / \mathrm{ml}$. Nevertheless, no data on responses in the patients with plasma concentration of $711 \mathrm{ng} / \mathrm{ml}$ are available.

\section{Discussion and Conclusion}

Using TDM in oncology could help to obtain adequate exposure as soon as possible and thus improve the treatment outcomes (Groenland et al., 2019), however, TDM conducting of PKls used in the breast cancer treatment is still not a part of routine patient care (Cardoso et al., 2020).

Except for everolimus for which the proposed $C_{\text {trough }}$ of $10 \mathrm{ng} / \mathrm{ml}$ is a promising target for TDM conduct, the TDM target for the other 5 TKIs has not been established yet. Provisionally, average $C_{\text {trough }}$ of responders could be used until special targets become available. However, in many cases there is limited response

Table $3-\mathrm{C}_{\text {trough }}$ proposed as a PK target of PKIs used in breast cancer treatment

\begin{tabular}{lccl}
\hline & $\begin{array}{c}\text { Suggested target } \\
\mathbf{C}_{\text {trough }}(\mathbf{n g} / \mathbf{m l})\end{array}$ & $\begin{array}{c}\text { Evidence } \\
\text { level }\end{array}$ & References \\
\hline Abemaciclib & $200-210$ & II & $\begin{array}{l}\text { Fujiwara et al. (2016), } \\
\text { Tate et al. (2018) }\end{array}$ \\
\hline Everolimus* & $12-19$ & I & $\begin{array}{l}\text { Deppenweiler et al. (2017), } \\
\text { Willemsen et al. (2018) }\end{array}$ \\
\hline Lapatinib & $>600$ & III & Josephs et al. (2013) \\
\hline Neratinib & $52-59$ & II & Burstein et al. (2010) \\
\hline Palbociclib & $>62$ & II & Mukai et al. (2019) \\
\hline Ribociclib & 711 & III & Samant et al. (2018) \\
\hline
\end{tabular}

*In everolimus, target $C_{\text {trough }}$ of $10-20 \mathrm{ng} / \mathrm{ml}$ is proposed. Everolimus $C_{\text {trough }}>10 \mathrm{ng} / \mathrm{ml}$ is associated with increased PFS, while $C_{\text {trough }}>20 \mathrm{ng} / \mathrm{ml}$ is associated with risk of overall severe toxicity. PK - pharmacokinetic; PKIs - protein kinase inhibitors; PFS - progression-free survival 
data when achieving the mean $\mathrm{C}_{\text {trough. }}$. Table 3 shows recently available data on average $\mathrm{C}_{\text {trough }}$ and everolimus proposed targets for breast cancer therapy. Nevertheless, it is necessary to conduct more prospective studies on feasibility, and utilization of TDM of PKIs to confirm its benefits. Thus, this review is not considered a manual for targeting mentioned concentrations in TDM of PKIs.

Although exposure-response relationships and clear proof of the clinical benefit of TDM of PKls are absent, these data could help to manage patients with predictive factors for pharmacological failure (Gougis et al., 2019) or patients with unexpected adverse events, or in cases with unsatisfactory efficacy, potential drug-drug interactions, or vulnerable patient populations (Groenland et al., 2019; Cardoso et al., 2020).

\section{References}

Burris, H. A. $3^{\text {rd }}$, Hurwitz, H. I., Dees, E. C., Dowlati, A., Blackwell, K. L., O’Neil, B., Marcom, P. K., Ellis, M. J., Overmoyer, B., Jones, S. F., Harris, J. L., Smith, D. A., Koch, K. M., Stead, A., Mangum, S., Spector, N. L. (2005) Phase I safety, pharmacokinetics, and clinical activity study of lapatinib (GW572016), a reversible dual inhibitor of epidermal growth factor receptor tyrosine kinases, in heavily pretreated patients with metastatic carcinomas. J. Clin. Oncol. 23, 5305-5313.

Burris, H. A. $3^{\text {rd }}$, Taylor, C. W., Jones, S. F., Koch, K. M., Versola, M. J., Arya, N., Fleming, R. A., Smith, D. A., Pandite, L., Spector, N., Wilding, G. (2009) A phase I and pharmacokinetic study of oral lapatinib administered once or twice daily in patients with solid malignancies. Clin. Cancer Res. 15, 6702-6708.

Burstein, H. J., Sun, Y., Dirix, L. Y., Jiang, Z., Paridaens, R., Tan, A. R., Awada, A., Ranade, A., Jiao, S., Schwartz, G., Abbas, R., Powell, C., Turnbull, K., Vermette, J., Zacharchuk, C., Badwe, R. (2010) Neratinib, an irreversible ErbB receptor tyrosine kinase inhibitor, in patients with advanced ErbB2-positive breast cancer. J. Clin. Oncol. 28, 1301-1307.

Cardoso, E., Guidi, M., Blanchet, B., Schneider, M. P., Decosterd, L. A., Buclin, T., Csajka, C., Widmer, N. (2020) Therapeutic drug monitoring of targeted anticancer protein kinase inhibitors in routine clinical use: A critical review. Ther. Drug Monit. 42, 33-44.

Chien, A. J., Munster, P. N., Melisko, M. E., Rugo, H. S., Park, J. W., Goga, A., Auerback, G., Khanafshar, E., Ordovas, K., Koch, K. M., Moasser, M. M. (2014) Phase I dose-escalation study of 5-day intermittent oral lapatinib therapy in patients with human epidermal growth factor receptor 2-overexpressing breast cancer. J. Clin. Oncol. 32, 1472-1479.

Chu, Q. S., Cianfrocca, M. E., Goldstein, L. J., Gale, M., Murray, N., Loftiss, J., Arya, N., Koch, K. M., Pandite, L., Fleming, R. A., Paul, E., Rowinsky, E. K. (2008) A phase I and pharmacokinetic study of lapatinib in combination with letrozole in patients with advanced cancer. Clin. Cancer Res. 14, 4484-4490.

Cizkova, M., Bouchalova, K., Friedecky, D., Polynkova, A., Janostakova, A., Radova, L., Cwiertka, K., Trojanec, R., Zezulova, M., Zlevorova, M., Hajduch, M., Melichar, B. (2012) High lapatinib plasma levels in breast cancer patients: risk or benefit? Tumori 98, 162-165.

Curigliano, G., Criscitiello, C., Esposito, A., Intra, M., Minucci, S. (2017) Pharmacokinetic drug evaluation of ribociclib for the treatment of metastatic, hormone-positive breast cancer. Expert Opin. Drug Metab. Toxicol. 13, 575-581.

Deppenweiler, M., Falkowski, S., Saint-Marcoux, F., Monchaud, C., Picard, N., Laroche, M. L., TubianaMathieu, N., Venat-Bouvet, L., Marquet, P., Woillard, J. B. (2017) Towards therapeutic drug monitoring of everolimus in cancer? Results of an exploratory study of exposure-effect relationship. Pharmacol. Res. 121, 138-144. 
Falkowski, S., Woillard, J. B. (2019) Therapeutic drug monitoring of everolimus in oncology: Evidences and perspectives. Ther. Drug Monit. 41, 568-574.

Flaherty, K. T., Lorusso, P. M., Demichele, A., Abramson, V. G., Courtney, R., Randolph, S. S., Shaik, M. N., Wilner, K. D., O'Dwyer, P. J., Schwartz, G. K. (2012) Phase I, dose-escalation trial of the oral cyclindependent kinase 4/6 inhibitor PD 0332991, administered using a 21-day schedule in patients with advanced cancer. Clin. Cancer Res. 18, 568-576.

Freedman, R. A., Gelman, R. S., Agar, N. Y. R., Santagata, S., Randall, E. C., Gimenez-Cassina Lopez, B., Connolly, R. M., Dunn, I. F., Van Poznak, C. H., Anders, C. K., Melisko, M. E., Silvestri, K., Cotter, C. M., Componeschi, K. P., Marte, J. M., Moy, B., Blackwell, K. L., Puhalla, S. L., Ibrahim, N., Moynihan, T. J., Nangia, J., Tung, N., Burns, R., Rimawi, M. F., Krop, I. E., Wolff, A. C., Winer, E. P., Lin, N. U.; Translational Breast Cancer Research Consortium (TBCRC) (2020) Pre- and postoperative neratinib for HER2-positive breast cancer brain metastases: Translational Breast Cancer Research Consortium 022. Clin. Breast Cancer 20, 145-151.e2.

Fujiwara, Y., Tamura, K., Kondo, S., Tanabe, Y., Iwasa, S., Shimomura, A., Kitano, S., Ogasawara, K., Turner, P. K., Mori, J., Asou, H., Chan, E. M., Yamamoto, N. (2016) Phase 1 study of abemaciclib, an inhibitor of CDK 4 and 6, as a single agent for Japanese patients with advanced cancer. Cancer Chemother. Pharmacol. 78, 281-288.

Gao, B., Yeap, S., Clements, A., Balakrishnar, B., Wong, M., Gurney, H. (2012) Evidence for therapeutic drug monitoring of targeted anticancer therapies. J. Clin. Oncol. 30, 4017-4025.

Gombos, A., Barthelemy, P., Awada, A. (2015) Evaluating the pharmacokinetics and pharmacodynamics of everolimus for treating breast cancer. Expert Opin. Drug Metab. Toxicol. 11, 823-834.

Gougis, P., Palmieri, L. J., Funck-Brentano, C., Paci, A., Flippot, R., Mir, O., Coriat, R. (2019) Major pitfalls of protein kinase inhibitors prescription: A review of their clinical pharmacology for daily use. Crit. Rev. Oncol. Hematol. 141, 112-124.

Groenland, S. L., Mathijssen, R. H. J., Beijnen, J. H., Huitema, A. D. R., Steeghs, N. (2019) Individualized dosing of oral targeted therapies in oncology is crucial in the era of precision medicine. Eur. J. Clin. Pharmacol.

75, 1309-1318.

Groenland, S. L., Martinez-Chavez, A., van Dongen, M. G. J., Beijnen, J. H., Schinkel, A. H., Huitema, A. D. R., Steeghs, N. (2020) Clinical pharmacokinetics and pharmacodynamics of the cyclindependent kinase 4 and 6 inhibitors palbociclib, ribociclib, and abemaciclib. Clin. Pharmacokinet.

59, 1501-1520.

Herviou, P., Thivat, E., Richard, D., Roche, L., Dohou, J., Pouget, M., Eschalier, A., Durando, X., Authier, N. (2016) Therapeutic drug monitoring and tyrosine kinase inhibitors. Oncol. Lett. 12, 1223-1232.

Infante, J. R., Cassier, P. A., Gerecitano, J. F., Witteveen, P. O., Chugh, R., Ribrag, V., Chakraborty, A., Matano, A., Dobson, J. R., Crystal, A. S., Parasuraman, S., Shapiro, G. I. (2016) A phase I study of the cyclin-dependent kinase 4/6 inhibitor ribociclib (LEE011) in patients with advanced solid tumors and lymphomas. Clin. Cancer Res. 22, 5696-5705.

Josephs, D. H., Fisher, D. S., Spicer, J., Flanagan, R. J. (2013) Clinical pharmacokinetics of tyrosine kinase inhibitors: Implications for therapeutic drug monitoring. Ther. Drug Monit. 35, 562-587.

Kirchner, G. I., Meier-Wiedenbach, I., Manns, M. P. (2004) Clinical pharmacokinetics of everolimus. Clin. Pharmacokinet. 43, 83-95.

Klumpen, H. J., Samer, C. F., Mathijssen, R. H., Schellens, J. H., Gurney, H. (2011) Moving towards dose individualization of tyrosine kinase inhibitors. Cancer Treat. Rev. 37, 251-260.

Kourie, H. R., Chaix, M., Gombos, A., Aftimos, P., Awada, A. (2016) Pharmacodynamics, pharmacokinetics and clinical efficacy of neratinib in HER2-positive breast cancer and breast cancer with HER2 mutations. Expert Opin. Drug Metab. Toxicol. 12, 947-957.

Roušarová J.; Šíma M.; Slanař O. 
Kovarik, J. M., Kaplan, B., Tedesco Silva, H., Kahan, B. D., Dantal, J., Vitko, S., Boger, R., Rordorf, C. (2002) Exposure-response relationships for everolimus in de novo kidney transplantation: Defining a therapeutic range. Transplantation 73, 920-925.

McShane, T. M., Wolfe, T. A., Ryan, J. C. (2018) Updates on managing advanced breast cancer with palbociclib combination therapy. Ther. Adv. Med. Oncol. 10, 1758835918793849.

Mukai, H., Shimizu, C., Masuda, N., Ohtani, S., Ohno, S., Takahashi, M., Yamamoto, Y., Nishimura, R., Sato, N. Ohsumi, S., Iwata, H., Mori, Y., Hashigaki, S., Muramatsu, Y., Nagasawa, T., Umeyama, Y., Lu, D. R., Toi, M. (2019) Palbociclib in combination with letrozole in patients with estrogen receptor-positive, human epidermal growth factor receptor 2-negative advanced breast cancer: PALOMA-2 subgroup analysis of Japanese patients. Int. J. Clin. Oncol. 24, 274-287.

Patnaik, A., Rosen, L. S., Tolaney, S. M., Tolcher, A. W., Goldman, J. W., Gandhi, L., Papadopoulos, K. P., Beeram, M., Rasco, D. W., Hilton, J. F., Nasir, A., Beckmann, R. P., Schade, A. E., Fulford, A. D., Nguyen, T. S., Martinez, R., Kulanthaivel, P., Li, L. Q., Frenzel, M., Cronier, D. M., Chan, E. M., Flaherty, K. T., Wen, P. Y., Shapiro, G. I. (2016) Efficacy and safety of abemaciclib, an inhibitor of CDK4 and CDK6, for patients with breast cancer, non-small cell lung cancer, and other solid tumors. Cancer Discov. 6, 740-753.

Ravaud, A., Urva, S. R., Grosch, K., Cheung, W. K., Anak, O., Sellami, D. B. (2014) Relationship between everolimus exposure and safety and efficacy: Meta-analysis of clinical trials in oncology. Eur. J. Cancer 50, 486-495.

Samant, T. S., Dhuria, S., Lu, Y., Laisney, M., Yang, S., Grandeury, A., Mueller-Zsigmondy, M., Umehara, K., Huth, F., Miller, M., Germa, C., Elmeliegy, M. (2018) Ribociclib bioavailability is not affected by gastric pH changes or food intake: In silico and clinical evaluations. Clin. Pharmacol. Ther. 104, 374-383.

Sancho-Garnier, H., Colonna, M. (2019) Breast cancer epidemiology. Presse Med. 48, 1076-1084. (in French)

Shah, A., Bloomquist, E., Tang, S., Fu, W., Bi, Y., Liu, Q., Yu, J., Zhao, P., Palmby, T. R., Goldberg, K. B., Chang, C. J. G., Patel, P., Alebachew, E., Tilley, A., Pierce, W. F., Ibrahim, A., Blumenthal, G. M., Sridhara, R., Beaver, J. A., Pazdur, R. (2018) FDA approval: Ribociclib for the treatment of postmenopausal women with hormone receptor-positive, HER2-negative advanced or metastatic breast cancer. Clin. Cancer Res. 24, 2999-3004.

Shipkova, M., Hesselink, D. A., Holt, D. W., Billaud, E. M., van Gelder, T., Kunicki, P. K., Brunet, M., Budde, K., Barten, M. J., De Simone, P., Wieland, E., Lopez, O. M., Masuda, S., Seger, C., Picard, N., Oellerich, M., Langman, L. J., Wallemacq, P., Morris, R. G., Thompson, C., Marquet, P. (2016) Therapeutic drug monitoring of everolimus: A consensus report. Ther. Drug Monit. 38, 143-169.

Stein, J., Mann, J. (2016) Specialty pharmacy services for patients receiving oral medications for solid tumors. Am. J. Health Syst. Pharm. 73, 775-796.

Strobbe, G., Pannier, D., Sakji, I., Villain, A., Feutry, F., Marliot, G. (2020) Advantages of everolimus therapeutic drug monitoring in oncology when drug-drug interaction is suspected: a case report. J. Oncol. Pharm. Pract. 26, 1743-1749.

Takasaki, S., Yamaguchi, H., Kawasaki, Y., Kikuchi, M., Tanaka, M., Ito, A., Mano, N. (2019) Long-term relationship between everolimus blood concentration and clinical outcomes in Japanese patients with metastatic renal cell carcinoma: a prospective study. J. Pharm. Health Care Sci. 5, 6.

Tamura, K., Mukai, H., Naito, Y., Yonemori, K., Kodaira, M., Tanabe, Y., Yamamoto, N., Osera, S., Sasaki, M., Mori, Y., Hashigaki, S., Nagasawa, T., Umeyama, Y., Yoshino, T. (2016) Phase I study of palbociclib, a cyclin-dependent kinase 4/6 inhibitor, in Japanese patients. Cancer Sci. 107, 755-763.

Tate, S. C., Cai, S., Ajamie, R. T., Burke, T., Beckmann, R. P., Chan, E. M., De Dios, A., Wishart, G. N., Gelbert, L. M., Cronier, D. M. (2014) Semi-mechanistic pharmacokinetic/pharmacodynamic modeling of 
the antitumor activity of LY2835219, a new cyclin-dependent kinase 4/6 inhibitor, in mice bearing human tumor xenografts. Clin. Cancer Res. 20, 3763-3774.

Tate, S. C., Sykes, A. K., Kulanthaivel, P., Chan, E. M., Turner, P. K., Cronier, D. M. (2018) A population pharmacokinetic and pharmacodynamic analysis of abemaciclib in a phase I clinical trial in cancer patients. Clin. Pharmacokinet. 57, 335-344.

Thiery-Vuillemin, A., Mouillet, G., Nguyen Tan Hon, T., Montcuquet, P., Maurina, T., Almotlak, H., Stein, U., Montange, D., Foubert, A., Nerich, V., Pivot, X., Royer, B. (2014) Impact of everolimus blood concentration on its anti-cancer activity in patients with metastatic renal cell carcinoma. Cancer Chemother. Pharmacol. 73, 999-1007.

Thill, M., Schmidt, M. (2018) Management of adverse events during cyclin-dependent kinase 4/6 (CDK4/6) inhibitor-based treatment in breast cancer. Ther. Adv. Med. Oncol. 10, 1758835918793326.

van Erp, N. P., Gelderblom, H., Guchelaar, H. J. (2009) Clinical pharmacokinetics of tyrosine kinase inhibitors. Cancer Treat. Rev. 35, 692-706.

Verheijen, R. B., Yu, H., Schellens, J. H. M., Beijnen, J. H., Steeghs, N., Huitema, A. D. R. (2017) Practical recommendations for therapeutic drug monitoring of kinase inhibitors in oncology. Clin. Pharmacol. Ther.

102, 765-776.

Verheijen, R. B., Atrafi, F., Schellens, J. H. M., Beijnen, J. H., Huitema, A. D. R., Mathijssen, R. H. J., Steeghs, N. (2018) Pharmacokinetic optimization of everolimus dosing in oncology: A randomized crossover trial. Clin. Pharmacokinet. 57, 637-644.

Willemsen, A., de Geus-Oei, L. F., de Boer, M., Tol, J., Kamm, Y., de Jong, P. C., Jonker, M. A., Vos, A. H., Grootjans, W., de Groot, J. W. B., Mulder, S. F., Aarntzen, E., Gerritsen, W. R., van Herpen, C. M. L., van Erp, N. P. (2018) Everolimus exposure and early metabolic response as predictors of treatment outcomes in breast cancer patients treated with everolimus and exemestane. Target Oncol. 13, 641-648.

Wong, K. K., Fracasso, P. M., Bukowski, R. M., Lynch, T. J., Munster, P. N., Shapiro, G. I., Janne, P. A., Eder, J. P., Naughton, M. J., Ellis, M. J., Jones, S. F., Mekhail, T., Zacharchuk, C., Vermette, J., Abbas, R., Quinn, S., Powell, C., Burris, H. A. (2009) A phase I study with neratinib (HKI-272), an irreversible pan ErbB receptor tyrosine kinase inhibitor, in patients with solid tumors. Clin. Cancer Res. 15, 2552-2558.

Yu, H., Steeghs, N., Nijenhuis, C. M., Schellens, J. H., Beijnen, J. H., Huitema, A. D. (2014) Practical guidelines for therapeutic drug monitoring of anticancer tyrosine kinase inhibitors: Focus on the pharmacokinetic targets. Clin. Pharmacokinet. 53, 305-325.

Zhang, J., Yang, N., Ji, D., Shen, W., Li, W., Han, R., Wang, N., Tao, H., Chapman, S. C., Sykes, A. K., Zhang, W., Hu, X. (2021) A randomized phase I study of abemaciclib in Chinese patients with advanced and/or metastatic cancers. Target Oncol. 16, 177-187. 